\title{
ANALISIS PENGARUH PEMBERIAN KREDIT USAHA RAKYAT (KUR) BRI UNIT LAREN TERHADAP PENINGKATAN KEUNTUNGAN USAHA MIKRO (KECIL) DI KECAMATAN LAREN KABUPATEN LAMONGAN
}

\author{
*( Henny Mahmudah \\ Fakultas Ekonomi \\ Universitas Islam Lamongan
}

\begin{abstract}
ABSTRAK
Usaha mikro dan kecil memegang peran penting dalam pembangunan ekonomi karena tingkat penyerapan tenaga kerjanya yang relatif tinggi namun dengan keterbatasan modal yang dimiliki. Pada umumnya masalah yang dihadapi oleh usaha permodalan, dimana pengusaha mikro kecil tidak memiliki modal usaha yang cukup menjalankan usahanya. Penelitian ini bertujuan menganalisis peningkatan pendapatan sesudah memperoleh pinjaman Kredit Usaha Rakyat (KUR) dari BRI unit Laren. Obyek penelitiannya yaitu Usaha Mikro dan Kecil (UMK) yang menjadi nasabah KUR BRI Unit Laren dengan sampel sebanyak 32 nasabah. Berdasarkan data yang diperoleh hasil perhitungan persamaan regresi linier sebagai berikut : $Y=957014,9+0,320 \mathrm{X}$, hal tersebut berarti variabel modal pinjaman KUR berpengaruh positif terhadap penghasilan. Dari pengujian statistik individual (uji $t$ ) diperoleh nilai t-hitung sebesar 2,045 modal pinjaman KUR $<$ dari $p$ value. Dengan demikian dapat disimpulkan bahwa kredit berpengaruh positif terhadap penghasilan, karena $p$ value modal pinjaman KUR $<5 \%$ atau significant pada $5 \%$ sehingga apabila modal pinjaman KUR semakin baik maka penghasilan Usaha Mikro dan Kecil (UMK) juga akan mengalami peningkatan. Nilai koefisien determinasi (R2) sebesar 0,496. Hal ini berarti bahwa 49,6\% penghasilan Usaha Mikro dan kecil (UMK) dipengaruhi oleh besarnya modal pinjaman KUR, sedangkan sisanya dipengaruhi oleh variabel lain.
\end{abstract}

Kata Kunci : Pinjaman KUR, Keuangan Usaha Mikro dan Kecil (UMK)

\section{LATAR BELAKANG}

Usaha mikro dan kecil memegang peran penting dalam pembangunan ekonomi karena tingkat penyerapan tenaga kerja relatif tinggi dan kebutuhan modal investasinya kecil. Rendahnya tingkat investasi dan produktivitas, serta rendahnya pertumbuhan usaha baru di
Indonesia perlu memperoleh perhatian yang serius pada masa yang akan datang dalam rangka mengembangkan Usaha Mikro dan Kecil (UMK) menuju usaha yang berdaya saing tinggi.

Berdasarkan data dari BPS tahun 2010 menyatakan bahwa terdapat 33.221 perusahaan industri / unit di kabupaten 
Lamongan. Angka tersebut mencakup seluruh perusahaan. Dilihat dari jumlah unit UMKM rata-rata dari tahun 20072010 yaitu sebesar 33.002, angka tersebut mencakup seluruh perusahaan UMK. UMK sangat berperan penting dalam penyerapan tenaga kerja dan kesempatan membuka usaha di kabupaten Lamongan.

$\begin{array}{ccc}\text { Peran } & \text { perbankan } & \text { dalam } \\ \text { pembangunan } & \text { ekonomi } & \text { adalah }\end{array}$
mengalirkan dana bagi kegiatan ekonomi yaitu salah satunya dalam bentuk perkreditan bagi masyarakat perseorangan atau badan usaha. Bank Rakyat Indonesia (BRI) memiliki komitmen untuk membantu mengembangkan Usaha Mikro Kecil dan Menengah (UMK) serta meningkatkan kesejahteraan masyarakat. Salah satu bentuk komitmennya adalah dengan dibukanya Kredit untuk Modal Usaha bagi UMK dan Koperasi untuk mendapatkan modal usaha.

BRI unit Laren merupakan salah satu unit kerja di BRI cabang Lamongan yang memiliki debitur yang dapat dikatakan cukup banyak. Hal ini dapat dilihat dari tingkat realisasi KUR BRI pada tahun 2009 sebesar Rp.11.941.073.623,00 sehingga rata-rata yang didapat adalah Rp.852.933.830,00. BRI unit Laren mengeluarkan realisasi sebesar Rp.1.443.399.360,00 berada di urutan kedua. Pada 2010 meningkat 13,7 $\%$ sehingga rata-rata perolehan sebesar Rp.989.279.282,00. Pada 2011 jumlah realisasi KUR meningkat sebesar 36,4\% dari tahun sebelumnya. Maka rata-rata diperoleh sebesar Rp.1.556.122.127,00.

KUR diberikan oleh BRI Unit Laren kepada para pengusaha mikro dan kecil di kecamatan Laren yang mengalami kekurangan modal dalam pengembangan usahanya. Modal merupakan aspek paling berpengaruh dalam mendirikan suatu usaha. Jika modal yang digunakan tidak sebanding dengan jumlah produksi yang dilakukan, maka produsen harus mengurangi jumlah produksinya sesuai dengan modal yang di punya. Dengan keterbatasan modal yang dialami oleh sebagian besar pengusaha mikro dan kecil kecamatan Laren.

\section{METODE}

Dalam penelitian yang dilakukan di BRI unit Laren ini, peneliti menggunakan metode kualitatif yang kemudian dirubah menjadi metode kuantitatif. Dalam penelitian ini menggunakan Uji validitas, Uji Reliabilitas, Regresi Linier Sederhana, Korelasi sederhana, Uji t.

\section{HASIL DAN PEMBAHASAN}

1. Responden tingkat Pendidikan

Dari 32 responden yang diwawancarai, sebanyak 90,62\% penghasilannya meningkat setelah meminjam kredit uaha rakyat dari Bank BRI kecamatan Laren, 6,25 $\%$ dari responden penghasilannya sama saja dan $3,1 \quad \%$ penghasilannya menurun karena penggunaan kredit tidak produktif. 
TABEL

HUBUNGAN TINGKAT PENDIDIKAN DENGAN TINGKAT KEUNTUNGAN

SETELAH MENERIMA KUR

\begin{tabular}{|c|c|c|c|c|c|c|c|c|c|c|c|}
\hline no & $\begin{array}{c}\text { Penghasilan } \\
\text { per bulan }\end{array}$ & \multicolumn{9}{|c|}{ Tingkat kondisi Pendidikan } \\
\cline { 3 - 13 } & & SD & $\%$ & SMP & $\%$ & SMA & $\%$ & D3 & $\%$ & S1 & $\%$ \\
\hline 1 & Meningkat & & & 4 & 12,5 & 7 & 21,8 & 12 & 37,5 & 6 & 18,7 \\
\hline 2 & Tetap & & & 1 & 3,1 & 1 & 3,1 & & & & \\
\hline 3 & Menurun & 1 & 3.1 & & & & & & & & \\
\hline & Jumlah & 1 & 3,1 & 5 & 15,6 & 8 & 24,9 & 12 & 37,5 & 6 & 18,7 \\
\hline
\end{tabular}

Tabel diatas menunjukkan tingkat sebesar $56,2 \%$ dan responden yang pendidikan mempengaruhi keberhasilan dalam meningkatkan keuntungan.3,1\% tamatan SD usia $\geq 50$ sebesar $3,1 \%$ menurun, 15,6\% tamatan SMP tetap dan meningkat, $24,9 \%$ tamatan SMA tetap dan meningkat, $37,5 \%$ tamatan D3 meningkat, $18,7 \%$ tamatan S1 meningkat.

2. Responden tingkat Usia

Usia juga berpengaruh terhadap penggunaan Kredit Usaha Rakyat (KUR) dalam menjalankan usahanya.

TABEL USIA RESPONDEN

\begin{tabular}{|c|c|c|c|}
\hline $\mathrm{NO}$ & $\begin{array}{l}\text { USIA } \\
(\mathrm{TH})\end{array}$ & $\begin{array}{c}\text { JUMLAH } \\
\text { NASABAH }\end{array}$ & $\%$ \\
\hline 1 & $\leq 30$ & 2 & 6,2 \\
\hline 2 & $31-40$ & 11 & 34,3 \\
\hline 3 & $41-50$ & 18 & 56,2 \\
\hline 4 & $\geq 50$ & 1 & 3,1 \\
\hline \multicolumn{2}{|c|}{ JUMLAH } & 32 & 100 \\
\hline
\end{tabular}

Dari tabel diatas ternyata responden lebih banyak yang memiliki usia $\leq 30$ tahun sebesar 6,2 \%, diantara 31-40 tahun sebesar $34,3 \%$, diantara 41-50 tahun

TABEL

\begin{tabular}{|c|c|c|c|c|c|}
\hline $\begin{array}{c}\text { Mo } \\
\text { del }\end{array}$ & R & $\begin{array}{c}\text { R } \\
\text { Squ } \\
\text { are }\end{array}$ & $\begin{array}{c}\text { Adju } \\
\text { sted } \\
\mathrm{R} \\
\text { Squar } \\
\text { e }\end{array}$ & $\begin{array}{c}\text { Std.Error } \\
\text { of the } \\
\text { Estimate }\end{array}$ & $\begin{array}{c}\text { Durb } \\
\text { in- } \\
\text { Wats } \\
\text { on }\end{array}$ \\
\hline 1 & .7 & .528 & .496 & $\begin{array}{c}379104.6 \\
67\end{array}$ & $\begin{array}{c}1.84 \\
0\end{array}$ \\
& & & 6655 & \\
\hline
\end{tabular}

KOEFISIEN DETERMINASI (R-

$$
\text { SQUARE) }
$$

Model Summary b

a Predictors: (Constant), $\mathrm{X}$

b Dependent Variabel : Y

Dari tabel diatas diperoleh RSquare $=0,528$ atau $5,28 \%$ dan sisanya $47,2 \%$ dejelaskan variabel lain yang tidak diikutsertakan dalam model estimasi.

Uji Validitas untuk nilai koefisien Determinasi R-Square $=0,496$ atau 49,6 $\%$. Hal ini berarti bahwa 49,6 \% penghasilan Usaha Mikro dan Kecil (UMK) dipengaruhi oleh besarnya 
modal pinjaman KUR, sedangkan sisanya dipengaruhi oleh variabel lain.

Uji Reliabititas diperoleh $\alpha$ (konstanta) sebesar 957014,9 maka dapat digunakan regresi sederhana $\mathrm{Y}=$ $957014,9+0,320 \mathrm{X}$, persamaan tersebut berarti variabel modal pinjaman KUR terikat atau berpengaruh positif terhadap penghasilan. Semakin tinggi modal kredit maka akan semakin tinggi pula perubahan tingkat keuntungan yang akan didapatkan pengusaha UMK di kecamatan Laren.

Hasil pengujian $\mathrm{Uji} \mathrm{t}$ diperoleh nilai $\mathrm{t}$ hitung 4,887 > t tabel 2,045, yaitu $\mathrm{Ha}$ diterima dan Ho ditolak. Artinya Modal Kredit Usaha (KUR) X mempunyai nilai $\mathrm{t}$ hitung variabel yang dominan terhadap tingkat pendapatan Pengusaha Usaha Mikro dan Kecil (UMK) pada tingkat kepercayaan $95 \%$.

\section{KESIMPULAN}

Berdasarkan hasil penelitian ini, dapat disimpulkan sebagai berikut :

1. Hasil persamaan $\mathrm{Y}=957014,9+$ $0,320 \mathrm{X}$, berarti Semakin tinggi modal kredit maka akan semakin tinggi pula perubahan tingkat keuntungan yang akan didapatkan pengusaha UMK di kecamatan Laren.

2. $\mathrm{t}$ hitung $4,887>\mathrm{t}$ tabel 2,045 , yaitu Ha diterima dan Ho ditolak. Artinya Modal Kredit Usaha (KUR) X mempunyai nilai t hitung variabel yang dominan terhadap tingkat pendapatan Pengusaha Usaha Mikro dan Kecil (UMK).

3. nilai koefisien Determinasi RSquare $=0,496$ atau 49,6 \%. Hal ini berarti bahwa 49,6 \% penghasilan Usaha Mikro dan Kecil (UMK) dipengaruhi oleh besarnya modal pinjaman KUR, sedangkan sisanya dipengaruhi oleh variabel lain.

\section{SARAN}

1. Meningkatnya keuntungan Usaha Mikro dan Kecil (UMK) setelah mendapatkan pinjaman KUR dari BRI Unit Laren hendaknya tetap dipertahabkan sampai pendapatan dari usaha yang dijalankan pengusaha Usaha Mikro dan Kecil (UMK) benar-benar dapat terus meningkat tanpa bantuan modal kredit dari bank maupun lembagalembaga keuangan lainnya.

2. Kredit yang disalurkan Bank BRI unit Laren hendaknya benar-benar digunakan untuk peningkatan atau sebagai penambah modal untuk UMK sehingga nantinya hasil usaha tersebut dapat dilipat gandakan untuk perkembangan UMK yang ada di Laren.

3.

\section{DAFTAR PUSTAKA}

Pinem, J, 2011. Implementasi Kredit Usaha Rakyat dalam Mengembangkan Usaha Kecil, skripsi pada Fakultas Ilmu Sosial dan Ilmu Politik Universitas Sumatera Utara

Pudjo Muljono, Teguh, 2009. Manajemen Pekreditan Bagi Bank Komersial, Yogyakarta : cetakan ke-3. BPFE Yogyakarta.

Sari, F, 2011. Peran Koperasi Simpan Pinjam Dalam Perkembangan 
UMKM Agribiniss, Bogor : Skripsi pada Departemen Agribisnis. Fakultas Ekonomi dan Manajemen, Institut Pertanian Bogor.

http:/www.galerikum.web.id/news/kriteria -usaha-mikro-kecil-dan-menengahumkm,10Juni 2012

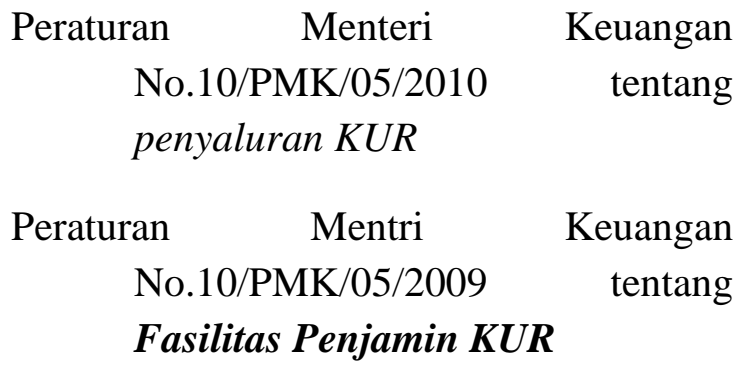

Peraturan Menteri Keuangan No.135/PMK.05/2008 tentang Penjamin Fasilitas KUR

Sugiono, 2008. Statistika untuk penelitian, Bandung : Alfabeta.

Wahana Komputer, 2009.SPSS 17, Untuk Pengolahan Data Statistik, Yogyakarta : Penerbit Andi.

Sumanjaya, Rakhmad, Syahrir Hakim Nasution, dan H.B. Tarmizi, 2008.

Teori Ekonomi Mikro. Medan : USU Press

Undang-undang No.20 tahun 2008 tentang Usaha Mikro Kecil dan
Menengah.

Kasmir, 2008. Bank dan Lembaga Keuangan Lainnya, Jakarta : PT.Raja Grafindo Persada. Edisi revisi.

Boediono, 2007.Ekonomi Mikro, Yogyakarta :BPFE. 